\title{
Evaluation of Groundwater Potential using Aquifer Characteristics of Parts of Boki Area, South - Eastern Nigeria.
}

Anthony Nuonum Ugbaja ( $\square$ anthonyugbaja@yahoo.com )

University of Calabar https://orcid.org/0000-0003-1790-7517

\section{Research Article}

Keywords: Vertical Electrical Sounding (VES), pumping test, Schlumberger array, Hydraulic parameters, potential zone

Posted Date: June 14th, 2021

DOI: https://doi.org/10.21203/rs.3.rs-382134/v1

License: @ (1) This work is licensed under a Creative Commons Attribution 4.0 International License. Read Full License 


\section{Abstract}

Vertical Electrical Sounding (VES) and pumping test (constant discharge and recovery test) was carried out in parts of Boki Local Government Area to evaluate the groundwater potential, using aquifer characteristics of the study area. Sixteen (16) VES point was employed for this study using the Schlumberger array, with a maximum spread of $400-600 \mathrm{~m}$. The stimulated result from the field data shows 3-5 layers resistivity model with the following curve types $\mathrm{A}, \mathrm{AK}, \mathrm{KH}, \mathrm{KHA}, \mathrm{QH}, \mathrm{QHA}$ and QHK. The geoelectric properties include resistivity of the various layers ranging from $33.58-2.29 \times 105 \Omega \mathrm{m}$, thickness from $0.2-50.2 \mathrm{~m}$, depth to basement varies from 2.99 $74.60 \mathrm{~m}$ across the study area. The litho logs show a top layer comprising of laterite, gravel/gravelly sand and siltstone intercalations and the layers underneath are made-up of clay, weathered basement containing migmatites and gneisses, fractured and unfractured basement are made up of granitic and metamorphic rocks. The weathered and fractured layers constitute the aquiferous layers in the study area. Hydraulic parameters were estimated from 16 pumped wells and results show transmissivity $(T)$ range of $4.1 \times 10-5-1.92 \times$ 10-1 m 2 /day, specific capacity (SC) ranges from 2.09-21.42m2 /day, hydraulic conductivity (K) varies from $2.6 \times 10-5$ - $3.0 \times 10$ $3 \mathrm{~m} /$ day and mean static water level (SWL) of $7.39 \mathrm{~m}$. Iso resistivity map of saprolite, fractured basement map, isopach map and the transmissivity map show that the studied area falls within the low-moderate groundwater potential zone.

\section{Introduction}

In the basement complex of the Obudu Plateau, ground water constitute the most reliable and major source of water for agricultural and domestic usage. It is found within the fractured / or weathered basement and are tapped by the use of hand-dug wells and boreholes .The discontinuous nature of the basement aquifers system makes detailed knowledge of the subsurface geology, it weathering depth and structural disposition through geologic and geophysical investigation inevitable (Adiat et.Al, 2009). This relatively low cost, high quality and quantity water source has not been properly exploited and managed, especially in developing countries. Bore-hole (water well) failures, waste of funds, abandonment of project, as well as, the lost of valuable quantitative and qualitative data on aquifer(s), characterized such areas. Therefore, there is a need for the application of geophysical and hydrological techniques such as electrical resistivity, seismic refraction, magnetic, electromagnetic, ground probing radar, pumping test, and down-hole logging in water project (Anomohanran, 2013). The electrical resistivity method (vertical electrical sounding) is used in determining the resistivity distribution of the subsurface, it is simple to apply in the assessment of groundwater occurrence (Okongboet al. 2011), as very detailed information are obtained about the thickness and resistivity of different conducting layers of the sub-surface. It is equally important that the aquifer parameters such as transmissivity, hydraulic conductivity, storativity, etc. are determined. The analysis of these hydrogeologic parameters can be achieved through several tests such as water quality analyses, down-hole logging and pumping test. These analyses are aimed at estimating the groundwater quality and the ability of the sub-surface formations to store and transmit groundwater. A combination of Geophysical methods, hydrogeologic parameter analyses and geological surveys will further provide the needed information. Therefore, it acts as a guide on the quality and quantity of the aquiferous layer, thereby reducing the number of failed water well/projects. They use of a systematic approach in prospecting for groundwater through exploring and exploitation of groundwater potential, for a steady, qualitative and quantitative supply. The development of ground water can be viewed as a sequential process with three major phases. There exploration phase, evaluation stage and the exploitation phase (Freeze and Cherry, 1979). The exploration phase involves the use of surface and sub- surface geological and geophysical techniques in search for suitable aquifers while the evaluation phase involve encompasses the measurement of hydro geologic parameters, the design and analyses of wells and the calculation of aquifer yield. Finally, the exploitation or management phase considers the impact between groundwater exploitation and hydro geologic system.

The aim of this work is to analyze the groundwater potential and aquifer characteristics of the study area, using electrical resistivity and pumping test to delineate groundwater aquifers for the citing of boreholes and the computation of the specific yield of the various boreholes.

\section{LOCATION OF STUDY AREA}

The study area is located between longitudes $6^{\circ} 0^{\prime} 0^{\prime \prime} \otimes 6^{\circ} 26^{\prime} 30^{\prime \prime} \mathrm{N}$ and latitude $8^{\circ} 30^{\prime} 20^{\prime \prime} \otimes 9^{\circ} 27^{\prime} 0^{\prime \prime}$. Boki is found in Cross River State, with a total landmass of about 1,070 square meters. The region is covered by the rainforest. The Boki area is an extension of the basement complex of the Obudu plateau, South -Eastern Nigeria, with the following dominant rock types Phylites, Hornblende schist,Gneisses,Migmatites, Igneous intrusive such as Granitoid,Dolerites,. They rocks display Porphyroblastic, Granoblastic, Xenoblastic textures in metamorphic rocks while porphyritic, xenomorphic, and mortar features are present in igneous rocks. Ukaegbu 
and Oti (2005) had observed that polydeformation has resulted in multi - directional orientation of planar and linear structure in the basement rock of southern Obudu Plateau (Fig. 1).

\section{Material And Method}

The acquisition of data was carried out in three phases, namely:

Geological or surface survey

Geophysical survey (VES)

Hydrogeology survey (pumping test)

Geologic survey or surface geology had involved research, planning, recognizance survey and interaction with the inhabitant of the study area. In geophysical survey, Vertical Electrical Survey (VES) was carried out.VES was carried out in 16 pre-determined communities (three VES points per sampled location) within parts of Boki Area in South-Eastern Nigeria using the Schlumberger array, with a maximum spacing of about $400-600 \mathrm{~m}$ between the current electrodes (Fig. 2). The process of carrying out resistivity involves the passage of current from the Geotron G41 terrameter into the ground through steel electrodes (current electrodes) which have been pinned into the ground resulting in creation of potential differences between the potential electrodes. The electrode where progressively expanded about a fixed point along the transverse line while maintaining the ratio of $1 / 5$ of the potential electrode spacing to the current spacing. Data generated were collected along the course of traversing the survey line. The electrodes are equidistant from the center of the survey line. The field data collected was recorded from the Terrameter in each electrodes spacing along the transverse line, the field data obtained was multiplied by the geometrical factor for the Schlumberger array $\left(G=\mathbb{G} / 4\left[\mathrm{~L}^{2}-\mathrm{a}^{2}\right] / \mathrm{a}\right)$ to find the apparent resistivity. The data was analyzed and interpreted using a computer designed software called Interprex ID.

In hydrogeology survey, 16 wells (single wells were used due to the absences of Observation Wells) within the pre-selected communities within parts of Boki local area, was pumped at a constant rate until a near steady/steady state was attained using 1.0Hp (horse power) submersible Pump, dip meter and a stopwatch was used to measure the corresponding changes (drawdown) in the water level and the respective time. Prior to the pumping, the static water level (SWL) was obtained using the dip meter, coordinates and elevation was equally obtained using the Global position system (GPS) whiles a calibrated (20) twenty liters container was used in estimating the pumping rate. For the recovery test, the submersible pump was switched off, the aquifer allowed to recharge and the corresponding time and water level measurement was noted. The data generated was subjected topographical and analytical analysis in estimating transmissivity of the aquifer $(T)$, hydraulic conductivity (K), specific capacity (SC), thickness (B) and drawdown(s). Transmissivity is defined as the product of the average hydraulic conductivity ( $k$ ) of the aquifer and the saturated thickness of the aquifer (B).

Transmissivity may be viewed as the rate of flow under a unit hydraulic gradient through a cross section of unit-width over the saturated thickness of the aquifer. It is expressed mathematically as follows:

\section{$\mathrm{T}=\mathrm{KB}$}

Where

$\mathrm{T}=$ transmissivity in $\mathrm{m}^{2} /$ day

$\mathrm{K}=$ hydraulic conductivity in $\mathrm{m} /$ day

$B=$ depth in $m$

Similarly, transmissivity can be computed using Cooper $\mathbb{U}$ Jacob straight line equation, where transmissivity $(\mathrm{T})$ is given by the equation:

$\mathrm{T}=2.3 \mathrm{Q} / 4 \rrbracket \Delta \mathrm{s}$

$\mathrm{Q}=$ Constant pumping rate

$\Delta s=$ Drawdown difference per log cycle. From the time- drawdown curves plots; $\Delta s$ is given by the equation:

$\Delta \mathrm{s}=\mathrm{S}_{2}-\mathrm{S}_{1} / \log \mathrm{T}_{2}-\log \mathrm{T}_{1}$ 
Where

$\mathrm{S}_{2}=$ drawdown at point 2

$\mathrm{S}_{1}=$ drawdown at point 1

$\log T_{2}=$ logarithm cycle of time 2

$\log T_{1}=\log a r i t h m$ cycle of time

Specific capacity (SC) is the volume of water that an aquifer would release from storage per unit surface area of the aquifer per unit decline in water table. It is equally defined as the rate per drawdown. It is expressed mathematically as follows:

$\mathrm{SC}=\mathrm{Q} / \mathrm{s}$ in $\mathrm{m}^{3} /$ day

Where

$\mathrm{Q}=$ Discharge rate in $\mathrm{m}^{2} /$ day

$\mathrm{s}=$ Drawdown in $\mathrm{m}$

Hydraulic Conductivity $(k)$ is the quantitative measurement of permeability, Permeability is the ease in which water can pass through a unit thickness of an aquifer and is measured in meter per day $(\mathrm{m} / \mathrm{s})$. Hydraulic conductivity $(\mathrm{K})$ is computed as follows:

$\mathrm{T}=\mathrm{kb}$

\section{Results And Discussion}

From the geo-electric curves simulated, the curve type varies from $K, A, H, K H, H K A, Q H A, Q H K$ and HAA type, showing that the sub surface formations varies in composition (complex) and are associated within the study area. The resistivity curve shows a $3,4,5$ geoelectric layers within the study area. FIG 3 and 4 are typical ID resistivity curves of sampled VES stations showing apparent resistivity, calculated result and computed model. Table 1 shows a summary of the geo electric properties of the sample location.

TABLE 1

Geoelectric Properties of the Study Area

$\begin{array}{llllr}\text { Location } & \begin{array}{l}\text { No } \\ \text { oflayers }\end{array} & \begin{array}{l}\text { Curve } \\ \text { type }\end{array} & \text { Resistivity } & \text { Thickness } \\ \text { basement }\end{array}$

\begin{tabular}{|c|c|c|c|c|c|c|c|c|c|c|c|c|c|c|}
\hline & & \multirow[b]{2}{*}{ 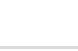 } & & & & & & & & & & & & \\
\hline & & & $\rho 1$ & $\rho 2$ & $\rho 3$ & $\rho 4$ & $\rho 5$ & $\rho 6$ & h1 & h2 & h3 & h4 & h5 & \\
\hline $\begin{array}{l}\text { Govt. PS, } \\
\text { Okubuchi }\end{array}$ & 4 & $\mathrm{KH}$ & 219.57 & 918.63 & 55.22 & 37016 & & & 0.327 & 3.313 & 6.228 & & & 9.87 \\
\hline EsekweIrruan & 3 & A & 211.43 & 325.22 & 80126 & & & & 1.922 & 22.748 & & & & 24.67 \\
\hline Ntamante & 4 & $\mathrm{HK}$ & 163.29 & 659.73 & 39.54 & $3.01 \mathrm{E}+05$ & & & 4.96 & 3.52 & 8.75 & & $\alpha$ & 17.23 \\
\hline Katchuan II & 5 & HKA & 1169.5 & 565.80 & 3519.2 & 116.41 & 2145.9 & & 1.9218 & 3.117 & 3.719 & 9.667 & & 17.70 \\
\hline Wula & 6 & KQA & 111.08 & 300.82 & 92.805 & 772.31 & 1821.3 & $2.29 \mathrm{E}+05$ & 1.41 & 0.62 & 4.28 & 28.0 & 16.71 & 51.03 \\
\hline Agba II & 4 & $\mathrm{HK}$ & 342.73 & 254.61 & 204.11 & 304.04 & & & 1.94 & 22.43 & 50.23 & & & 74.60 \\
\hline Biajua & 6 & QHK & 754.12 & 293.9 & 252.16 & 9.710 & 758.01 & 0.1717 & 0.26 & 8.034 & 0.459 & 5.43 & 17.86 & 31.63 \\
\hline Biatiah & 3 & K & 451.48 & 692.3 & 3974 & & & & 1.94 & 10.64 & & & & 12.58 \\
\hline UnkoBeteriko & 3 & $\mathrm{H}$ & 7248 & 89.659 & 699.9 & & & & 3.92 & 0.79 & & & & 4.70 \\
\hline Daneri II & 4 & $\mathrm{KH}$ & 2318.0 & 3262.0 & 56.70 & 1350 & & & 2.07 & 1.179 & 0.880 & $\alpha$ & & 4.13 \\
\hline Okundi & 5 & QHA & 1537.3 & 1002.4 & 159.04 & 13116 & 21.43 & & 0.60 & 11.57 & 5.49 & 17.90 & $\alpha$ & 35.56 \\
\hline Arunkawa`Gom & 6 & HAA & 1427.1 & 241.48 & 7039.8 & 60.29 & 2039.4 & 137470 & 0.4618 & 2.47 & 0.28 & 8.28 & 8.99 & 20.48 \\
\hline Effigbo & 5 & $\mathrm{KH}$ & 286.5 & 109.52 & 2136.1 & 179.91 & 39905 & & 5.885 & 3.191 & 11.414 & 18.847 & $\alpha$ & 39.34 \\
\hline Orimekpan & 4 & AAA & 857.34 & 1197.2 & 310.95 & 11310 & & & 1.40 & 18.6 & 18.8 & $\alpha$ & & 38.89 \\
\hline EdohIrruan & 5 & KHA & 342.66 & 1560.3 & 228.75 & 890 & $2.21 \mathrm{E}+05$ & & 0.94 & 0.62 & 3.21 & 46.8 & $\alpha$ & 50.86 \\
\hline
\end{tabular}

Geoelectric Sections 
The VES results were used in the preparation of 2-D geoelectric sections, which shows the resistivity of the various subsurface layers and their respective thickness (Fig 5-8). Each section was prepared in accordance to the VES points in each transverse. The geoelectric section is made up of 3-5 subsurface geoelectric units, inferred as laterite, gravel and gravelly sand; clay weathered and fractured basement, and fresh basement. The study area is made up of two aquifer type. Type1 are aquifer found on the overburden/weathered layers and are mostly exploited using hand dug well as a result of their near -to-surface depth while Type 2 aquifers are found on the fractured rocks of the basement complex. From the correlation of the geoelectric section along transverse section A-A $($ fig, 5) with the following sampled points (VES 13,12,6,14 respectively), the resistivity curves shows a 3-5 layer model with the following curve types $\mathrm{KH}, \mathrm{HAA}, \mathrm{HK}, \mathrm{AK}$ along the transverse line. These layers are laterite, gravelly sand, clay, weathered basement and the unweathered basement. The aquiferous layer for this transverse area is the weathered basement with resistivity values ranging from $60^{\prime} \Omega \mathrm{m}$ to $310 \mathrm{\prime} \mathrm{m}$ and thickness values ranging from $12 \mathrm{~m}$ at VES 12 to approximately $19 \mathrm{~m}$ at VES 6 . The area will support hand-dug wells as a result of the depth of the aquifer to the surface. The resistivity of the sampled area shows that the weathered basement has high clay content therefore; the aquifer yield will be low despite the size of the thickness of the overburden.

Transverse section $\mathrm{B}^{-} \mathrm{B}^{1}(\mathrm{fig}, 6)$ with the following(Ves16, 8, 15 and 11 respectively). The geoelectric sections shows 3-5 layers model with a curve type of $\mathrm{KH}, \mathrm{k}, \mathrm{KHA}$ and QHA.VES 15 showing a confined aquifer. The probable aquiferous layer for this transverse section would be the weathered layered and the fractured basement. The sampled section will support both motorized and hang dug well. The thickness of the aquiferous unit ranges from $4 \mathrm{~m}$ at VES 15 to $32 \mathrm{~m}$ at VES 16 with the fractured basement resistivity ranging from $890^{\prime} \mathrm{\Omega m}$ to $4153^{\prime} \mathrm{\Omega m}$. The geoelectric layers include laterite, gravelly sand clay, weathered basement, fractured basement and the fresh basement.

The transverse $C_{-1} C^{1}(f i g, 7)$ shows three locations within the study area namely (VES 9, 5, and 7) with a resistivity range of 89.59 to $229000 \mathrm{\prime} \mathrm{m}$. The geoelectric section shows show 3-5 layers model with the following curve type H, KQA, QHK. The geoelectric layers are interpreted as laterite, clay, weathered basement, fractured and unweathered basement, with VES 7 showing a multi aquifer system at a depth of $20.5 \mathrm{~m}-27.5 \mathrm{~m}$ and $30 \mathrm{~m}-33 \mathrm{~m}$. The possible aquiferous layer for VES 9 and 7 is the unconfined weathered basement while water can be tapped from a combination of the weathered and fractured basement in VES5.

\section{Isopach and iso resistivity map of the aquiferous layers}

The overburdens are laterite, gravel /gravelly sands, clays, weathered basement.The overburden thicknesses (depth to basement) range from $2.99 \mathrm{~m}$ at (lowest thickness) to $74.06 \mathrm{~m}$ at (highest thickness) with an average thickness of $27.26 \mathrm{~m}$ within the study area. The overburden thickness at each sounding location was gridded and contoured to produce an Isopach map (Fig.9) of the overburden. An isopach map shows the spatial distribution of thicknesses within a locality. The map was broken into four zones based on ground water potentials. They zones are Zone A (high:65 and above), B (moderate:45-65), C (low:25-45), and finally D (minimal;0-25). The zones weighted as follows Zone A 6.3\%, B 37.5\%, C 31\% and D 25\%. Based on the zoning the study area could be classified into low to moderate ground water zone. According to Olurunfemi and Okhue (1992), Oyedele and Olayinka (2012), a minimum overburden thickness of $25 \mathrm{~m}$ is required for viable ground water abstraction in the basement terrain. In the study area, the overburden thickness varies from 2.99 to $74.06 \mathrm{~m}$; an overburden thickness of 25 to $72 \mathrm{~m}$ occurred in $74 \%$ of the study area, showing a very thick overburden and thus should support productive groundwater abstraction. However, according to Lenkey et.al (2005) a thick weathered layer (containing less percentage of clay) above the basement rock will constitute a water bearing layer.

An Iso- resistivity map of the weathered basement (saprolite) was produced to show the spread of resistivity at a common depth within the study area and presented as Fig.11.The resistivity values of the saprolite (weathered basement) ranges from $33.58-918.63 \mathrm{~S} \mathrm{~m}$, an indication of the present of laterites/clay, clayey/clay and sandy clay. The Iso-resistivity map show that the resistivity of the weathered basement is broken into the following zones in terms of groundwater potential: high groundwater potential (>650' $\mathrm{m}$ ), moderate (400650'̊m), low (150-450), minimal (33.58-150).

Wright (1992), Mallam(2004) and Adelusiet.al,(2004) had developed a scheme for ranking of ground water potential as a function of saprolite (weathered basement) resistivity as presented in the Table 2. 


\begin{tabular}{|l|l}
\hline Saprolite resistivity $(\Omega \mathrm{m})$ & Aquifer characteristics \\
\hline$<20$ & Clayey with limited aquifer potential \\
\hline
\end{tabular}

\begin{tabular}{|l|lr}
\hline $20-100$ & \multicolumn{2}{|l}{ Optimum weathered and groundwater } \\
& potential & \\
\hline $101-150$ & $\begin{array}{l}\text { Medium aquifer conditions and } \\
\text { potential }\end{array}$ \\
\hline $151-300$ & Limited weathering and poor \\
& groundwater potential & \\
\hline$>300$ & Negligible &
\end{tabular}

Source: Oyedele et.al.( 2012)

From the table 2, the study area has $21.43 \%$ in the optimum weathered and ground water potential zone, $7.14 \%$ in the medium aquifer conditions and groundwater potential while $50 \%$ of the area within the study area is in the negligible zone with no appeal for groundwater potential. Finally, the limited weathering and poor groundwater potential zone constitute $21.43 \%$ of the study area. In the basement terrain, the aquiferous layers are usually found in the thick, porous weathered and the fractured part of the bedrock. The fractures are mostly associated with high ground water yield when compared with the overburden as a result of its relatively high permeability. A ranking scheme for aquifer potential, as a function of the fractured bedrock which was modified by Oyedele et al.,(2012) is shown in the table 3 below.

\section{Hydrological Analysis}

From the pumping test exercise carried out, the results obtained from the various pumped location is presented as table 3.Using Cooper -Jacob straight line equation, the data was handle graphically and analytically resulting in the plotting of time-drawdown curve on a semi-log graph for the various locations and the computation and analyses of aquifer parameters, here presented as appendix 2 and Table 3 respectively.

Table 3 The computation and analyses of aquifer parameters.

$\begin{array}{llll}\text { S/N Location } & \text { Transmissivity } & \text { Specific discharge } & \begin{array}{l}\text { Hydraulic } \\ \text { conductivity }\end{array} \\ \text { 1. Govt. PS, Okubuchi } & 0.00541 & 21.424 & 0.00055 \\ \text { 2. EsekweIrruan } & 0.00421 & 4.251 & 0.00017 \\ \text { 3. Ntamante } & 0.059 & 11.398 & 0.0034 \\ \text { 4. Katchuan II } & 0.0125 & 16.67 & 0.00071 \\ \text { 5. Wula } & 0.00263 & 15.807 & 0.000052 \\ \text { 6. Agba II } & 0.00373 & 10.725 & 0.00005 \\ \text { 7. Biajua } & 0.192 & 2.9108 & 0.0061 \\ \text { 8. BiatiahUnko } & 0.975 & 3.871 & 0.0776 \\ \text { 9. Beteriko I } & 0.00041 & 2.435 & 0.000087 \\ \text { 1C Daneri II } & 0.0258 & 3.184 & 0.0062 \\ \text { 11 Okundi } & 0.0262 & 7.376 & 0.00074 \\ \text { 12 ArunkawaGom } & 0.00845 & 16.386 & 0.00041 \\ \text { 12 Effigbo } & 0.00373 & 21 & 0.000095 \\ \text { 1 C Orimekpan } & 0.002605 & 2.089 & 0.000067 \\ \text { 1E EdohIrruan } & 0.00013 & 3.038 & 0.0000025 \\ \text { 16 Ajirija } & 0.0013 & 2.8943 & 0.00041\end{array}$


$\mathrm{T}=\mathrm{kb}$

$\mathrm{T} \quad=2.3 \mathrm{Q} / 4 \otimes \Delta \mathrm{s}$

(Cooper and Jacob 1946)

Table 3 show the computed transmissivity value for the study area, which ranges from 0.00013 to $0.975 \mathrm{~m}^{2} /$ day with an average transmissivity of $0.032 \mathrm{~m}^{2} /$ day within the pumped locations. Fig.4 is a transmissivity map showing the spatial distribution of transmissivity within the pumped locations in the study area. Offodite(2002),suggested a transmissivity range of 5 to $50 \mathrm{~m}^{2} /$ day to represent high groundwater potential in crystalline rock while $0.0155 \mathrm{~m}^{2} / \mathrm{s}(10000 \mathrm{gal} / \mathrm{day} / \mathrm{ft}$.) represent good aquifer for well exploitation(Cherry and Freeze 1979). However, the transmissivity range of the pumped wells within the study area was characterized by negligible to low ground water potential.

\section{Hydraulic Conductivity (k)}

Hydraulic conductivity is the quantitative measurement of permeability; permeability is the ease in which water can pass through a unit thickness of an aquifer. Hydraulic conductivity $(\mathrm{K})$ is obtained mathematically as follows:

$T=k b$

Where

$$
\mathrm{K}=\mathrm{T} / \mathrm{b}
$$

Where $\mathrm{K}, \mathrm{T}$ and $\mathrm{b}$ are as defined in the equation above

The value of $k$ varies from $0.0000025 \mathrm{~m} / \mathrm{d}$ to $0.0034 \mathrm{~m} / \mathrm{d}$ as shown in table 2 .

The table 4 shows the saturated hydraulic conductivities $(k)$ values found in nature.

Table 4 the saturated hydraulic conductivities (k) values found in nature.

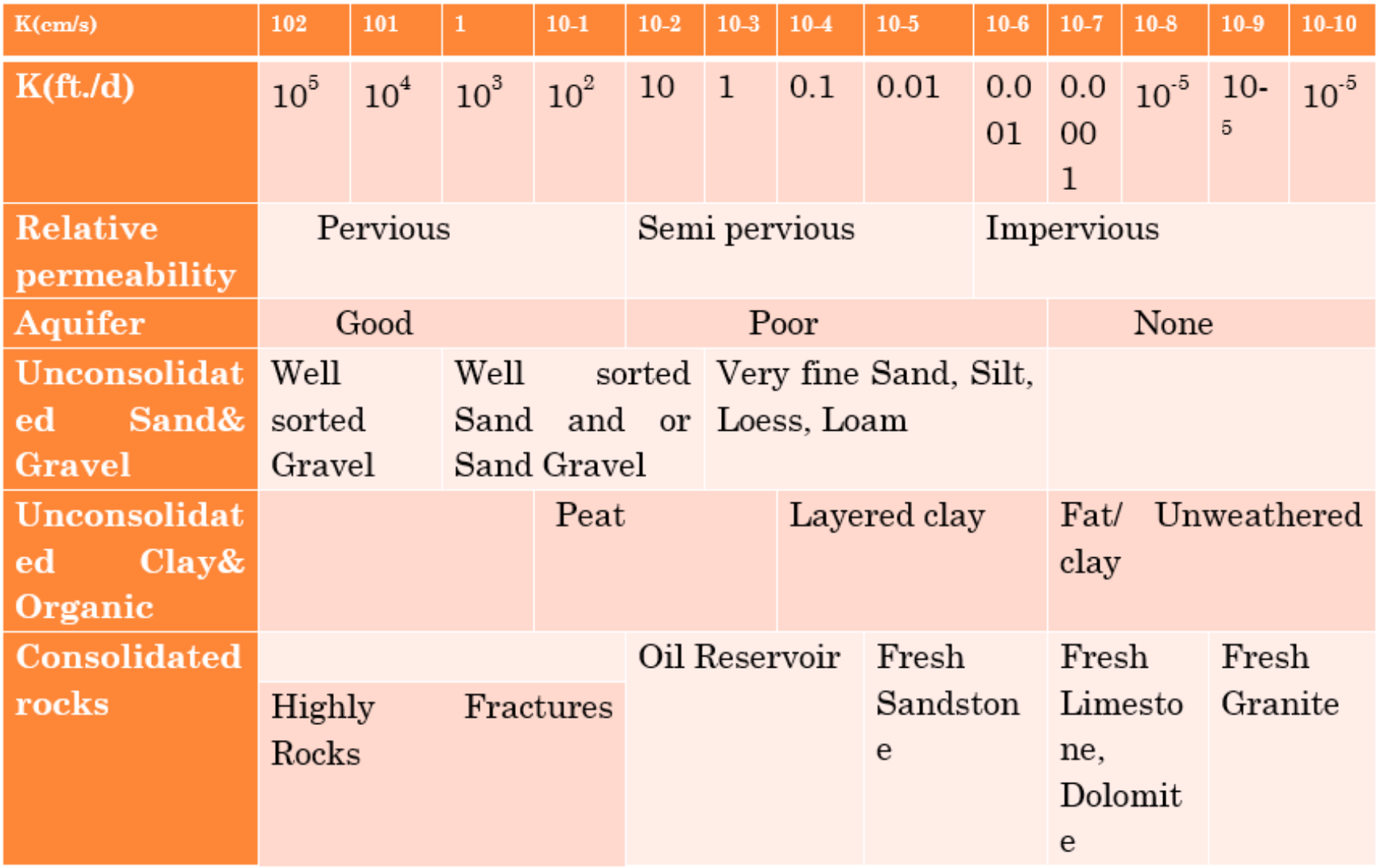


From the computed hydraulic conductivity on the table 2 for the study area, the sampled location falls within the semi pervious zone with poor ground water potential.

\section{Thickness of the Aquifer}

The aquifer thickness ranges from $2.2-50,22 \mathrm{~m}$, the aquifers which is found within the weathered materials and fracture zones of the overburden has high clay content, which is very typical of the Obudu Basement Complex, as it is still undergoing weathering. Although the study area is characterized by zones of high over burden thicknesses, its high clay content places it within the low groundwater potential zones.

From the hydraulic analysis, which had involved the abstraction of water from a single well at a controlled rate and the water level response (drawdown) was measured (pumping test). The static water level, drawdown, elevation, pump water level, installed depth was obtained at each site while the following hydraulic characteristic was computed from aquifer test analysis as shown in fig2. The software, aquifer test were used in modeling the pumping test data obtained in the study area. Transmissivity $(T)$ ranges from $0.00013 \mathrm{~m}^{2} / \mathrm{d}$ to $0.975 \mathrm{~m}^{2} / \mathrm{d}$, Specific discharge (SC) ranges from $2.09 \mathrm{~m}^{2} / \mathrm{d}$ to $21.42 \mathrm{~m}^{2} / \mathrm{d}$. Hydraulic conductivity (K) equally ranges from $0.0000026 \mathrm{~m} / \mathrm{d}$ to $0.003 \mathrm{~m} / \mathrm{d}$.

\section{Conclusion}

They use of geophysical and hydrogeological methods in the evaluation of the ground water potential, and aquifer characteristic in the study area have shown the following:

- The study area falls within the low-moderate ground water potential zone as shown by the Iso resistivity map of saprolite, fractured and weathered basement results, isopach map of the overburden, lithology logs and geoelectric sections, computed transmissivity values and map, specific capacity and hydraulic conductivity result of the study area. This low - moderate ground water potential which characterized the study area is probably as a result of the high clay content in the weathered basement complex of the Obudu plateau.

- The aquiferous units are the weathered and the fractured basement, with the fractured basement being more productive than the weathered basement as shown by the computed specific yield and transmissivity.

\section{Recommendation}

As a result of the low-moderate aquifer potential of the study area, mechanized farming should be discouraged; however, two bore holes can be cited 50 meters apart to improve the water supply within the farm.

The need for an observation wells in future study, this will help in the computation of storativity values.

\section{References}

1. Adelusi AO, Ayuk MA, Oyedele AA(2004) Hydrogeophysical Analysis of Owode Area around Oba-lle near Akure, south western Nigeria. African journal of development studies,4,11-14.

2. Adeoti I, Alile OM, Uchegbulam O, Adegbola RB (2012) Geoelectric investigation of groundwater potentials in Mowe, Ogun State. NigeriaBritish Journal of Applied Science Technology 2:58

3. Akintorinwa OJ (2015) Groundwater potential assessment of Iwaro-Oka. SW Nigeria using geoelectric parameter

4. Anomoharan $\mathrm{O}$ (2013) Evaluation of Aquifer Characteristics in Echir, Delta State, Nigeria using well logging and pumping test method. American Journal of Applied Science (10):1263-1269

5. Cooper H, H, (Jr) and Jacob CE (1946).A generalized graphical method for evaluating formation constant and well field history. Tran AmericanGeophysical Union, 27,526-534

6. Freeze RA, Cherry JA (1979) Ground water.New Jersey. Prentice Hall. Engle Wood Cliffs

7. Mallam A (2004) Fresh Basement Revealed from Resistivity Method. Zuma journal of Pure Allied Science 6:6-11

8. Olorunfemi MO, Okhue EJ (1992) Hydrogeologic and Geologic Significances of a Geoelectric survey at Ile-Ife. Nigeria Journalof Mining Geology 28:242-350

9. Offodile ME (2002).Groundwater Study and Development in Nigeria.Mecon. Services Ltd., Jos, Nigeria(5) pp 494-502 
10. Omosuyi GO(2010). Geoelectric Assessment of Groundwater Prospect and Vulnerability of Overburden Aquifer at Idara, SouthEastern Nigeria.Ozean Journal of Applied Science,3,19-28

11. Okongbo KS, Akoture E, Odubo E (2011).Determination of aquifer protection capacity and corosinity of near surface materials in Yeneogi city, Nigeria.Research Journal of Applied Science,Engineering andTechnology (3), 785-791

12. Oyeledele, AAandOlayinka, Al (2012) Statistical Evaluation of Groundwater Potential of Ado- Ekiti, South West Nigeria. Transnational Journal of Science Technology 2:110-127

13. Ukaegbu VU, Oti MN (2005) Structural elements of the Pan -African Orogeny and their geodynamic implications inObudu Plateau, Southeastern Nigeria. Journal of Mining Geology 41:41-49

14. Wright EP (1992) The Hydrogeology of Crystalline Basement in Aquifers in Africa. Geological Society of London special publications $66: 1-27$

\section{Appendix}

Appendix was not provided with this version.

\section{Figures}
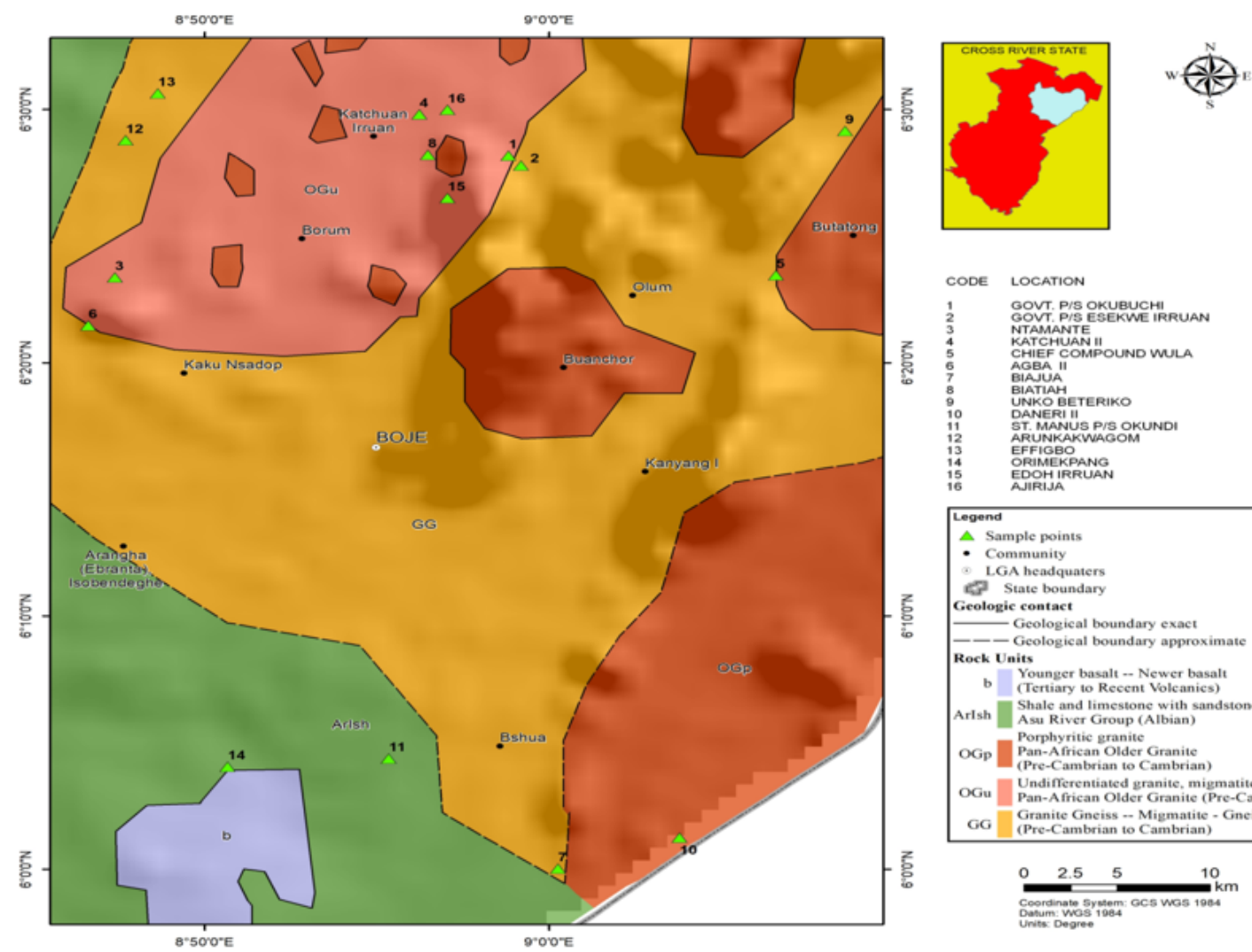

\section{Aample points}

- LGA beadquaters

cologic contact

- Geological boundary exact - - Geological boundary approximate ock Units

b Younger basalt - - Newer basali

Shale and limestone with sandstone interealations

Asa River Group (Albian)

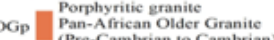

OGu Undifferentiated granite, migmatite and granite gneiss

OGu Pan-African Older Granite (Pre-Cambrian to Cambrian)

GG Granite Gneiss -- Migmatite - Gneiss Complex

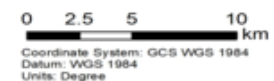

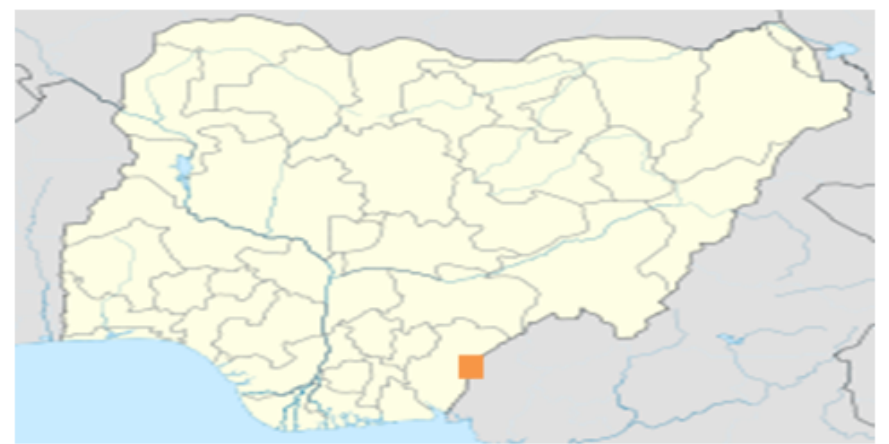

Figure 1 
Geologic/Sample location map of the study area. Note: The designations employed and the presentation of the material on this map do not imply the expression of any opinion whatsoever on the part of Research Square concerning the legal status of any country, territory, city or area or of its authorities, or concerning the delimitation of its frontiers or boundaries. This map has been provided by the authors.

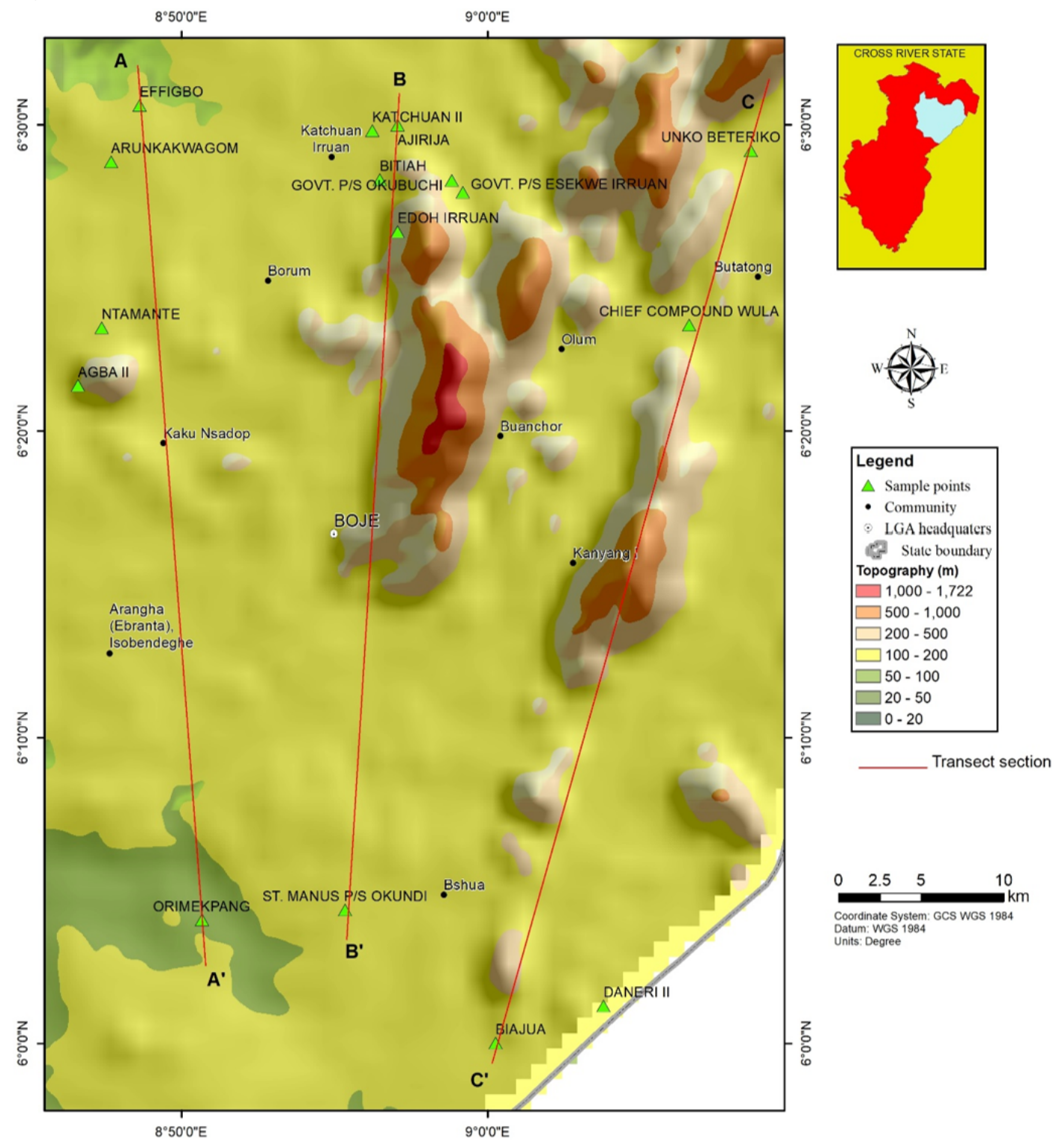

\section{Figure 2}

Topographic map, Transverse points, VES points, Borehole locations. Note: The designations employed and the presentation of the material on this map do not imply the expression of any opinion whatsoever on the part of Research Square concerning the legal status of any country, territory, city or area or of its authorities, or concerning the delimitation of its frontiers or boundaries. This map has been provided by the authors. 


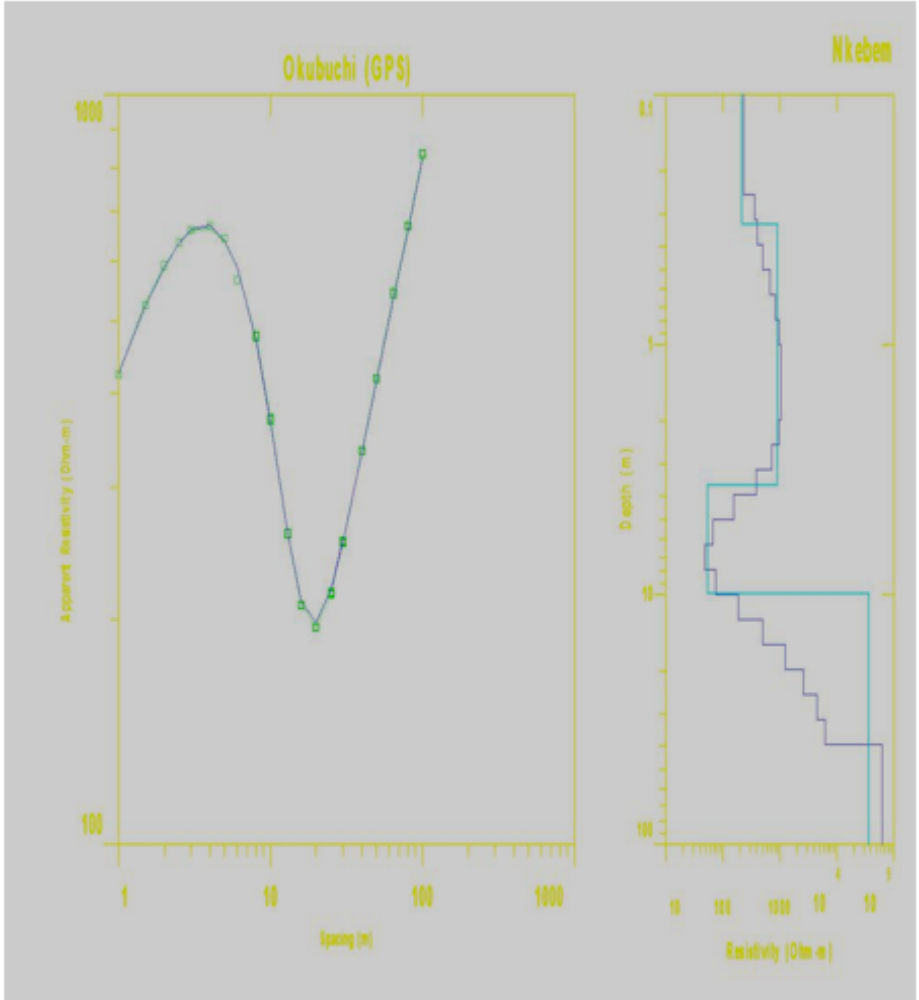

\section{Figure 3}

Okubuchi Schlumberger Configuration

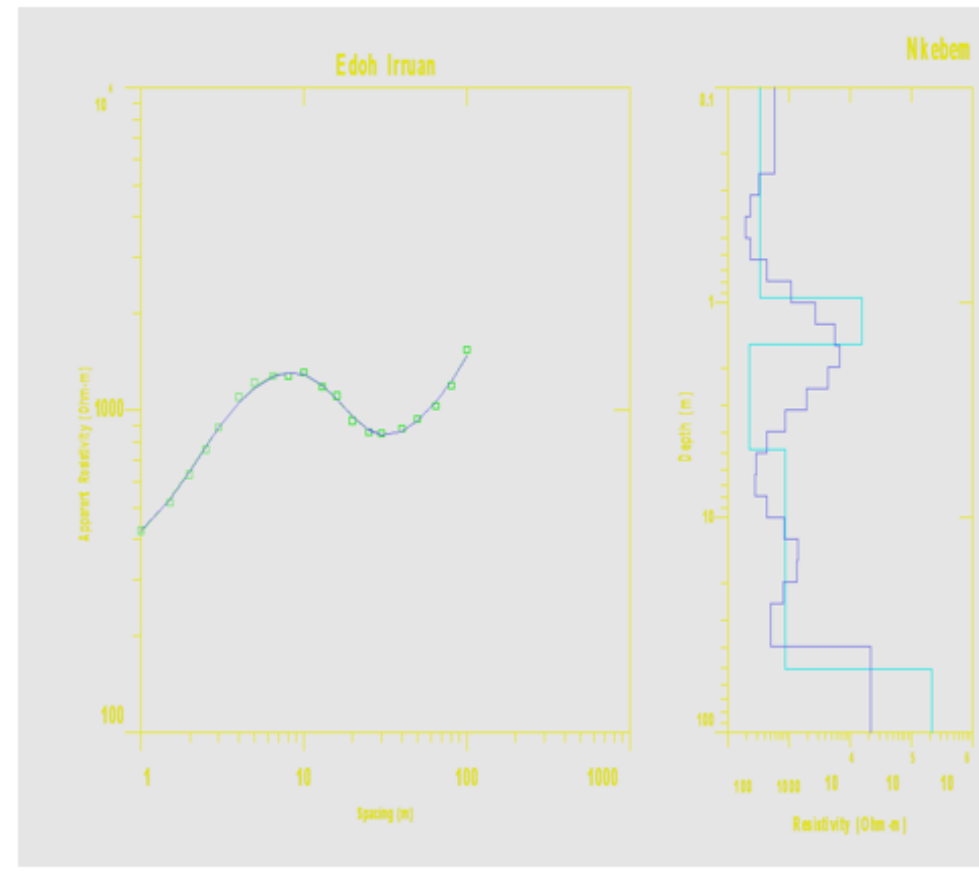

\section{Figure 4}

Edoh Irruan Schlumberger Configuration

\begin{tabular}{|l|l|l|l|}
\hline No. & RES & Thickness & Depth \\
\hline 1 & 219.57 & 0.32 & 0.32 \\
\hline 2 & 918.63 & 3.31 & 3.63 \\
\hline 3 & 55.22 & 6.29 & 10.6 \\
\hline 4 & 37016 & - & \\
\hline
\end{tabular}

$\mathrm{XXX}=$ Observed apparent resistivity $=$ Calculated apparent resistivity $=$ Computed apparent resistivity

\begin{tabular}{|l|l|l|l|}
\hline No. & RES & Thickness & Depth \\
\hline 1 & 211.43 & 1.92 & 1.92 \\
\hline 2 & 325.22 & 22.7 & 24.6 \\
\hline 3 & 80126 & & \\
\hline 4 & & - & \\
\hline
\end{tabular}

$\mathrm{XXX}=$ Observed apparent resistivity $=$ Calculated apparent resistivity

$=$ Computed apparent resistivity 


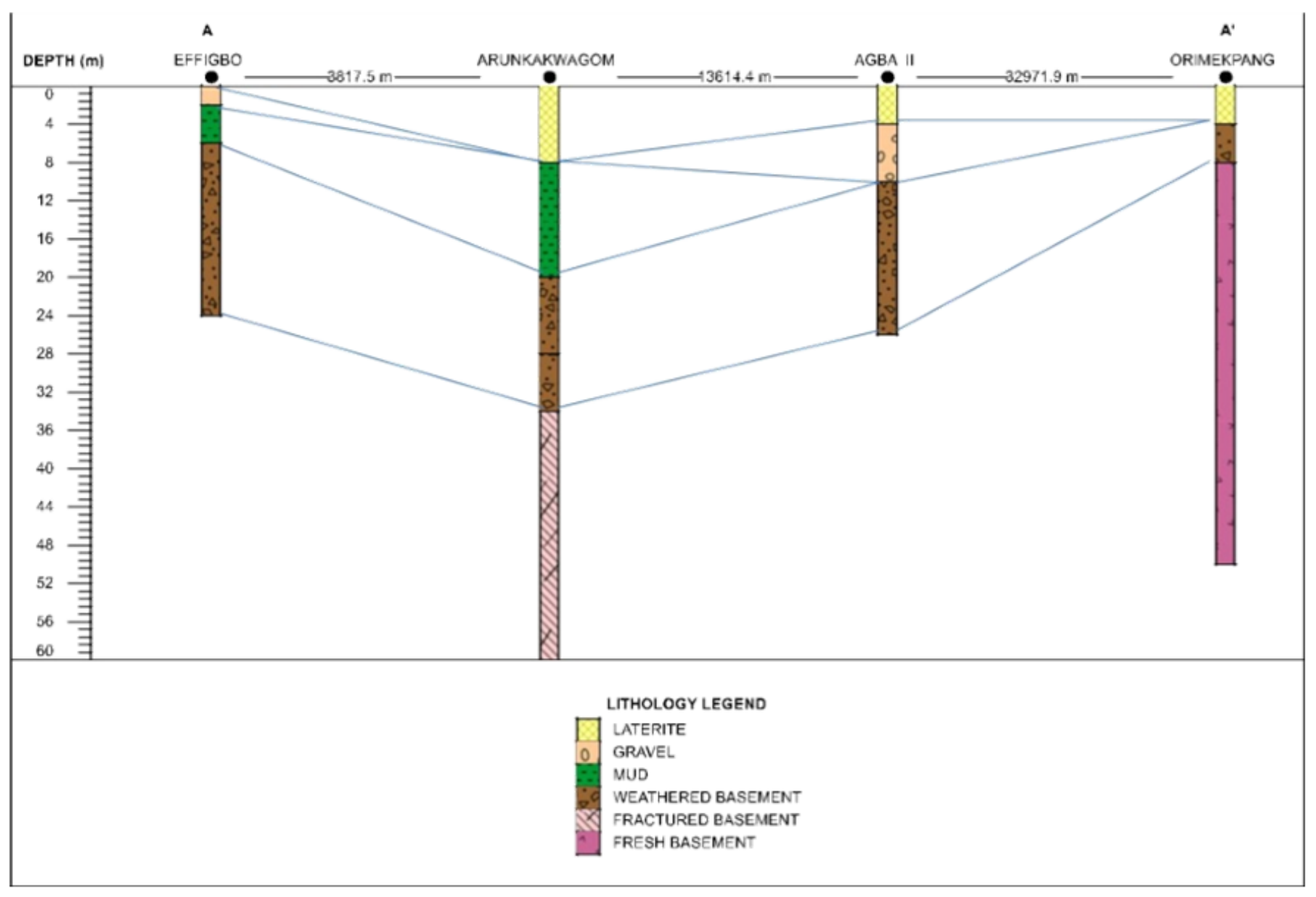

Figure 5

Geoelectric sections for traverse A-A1. 


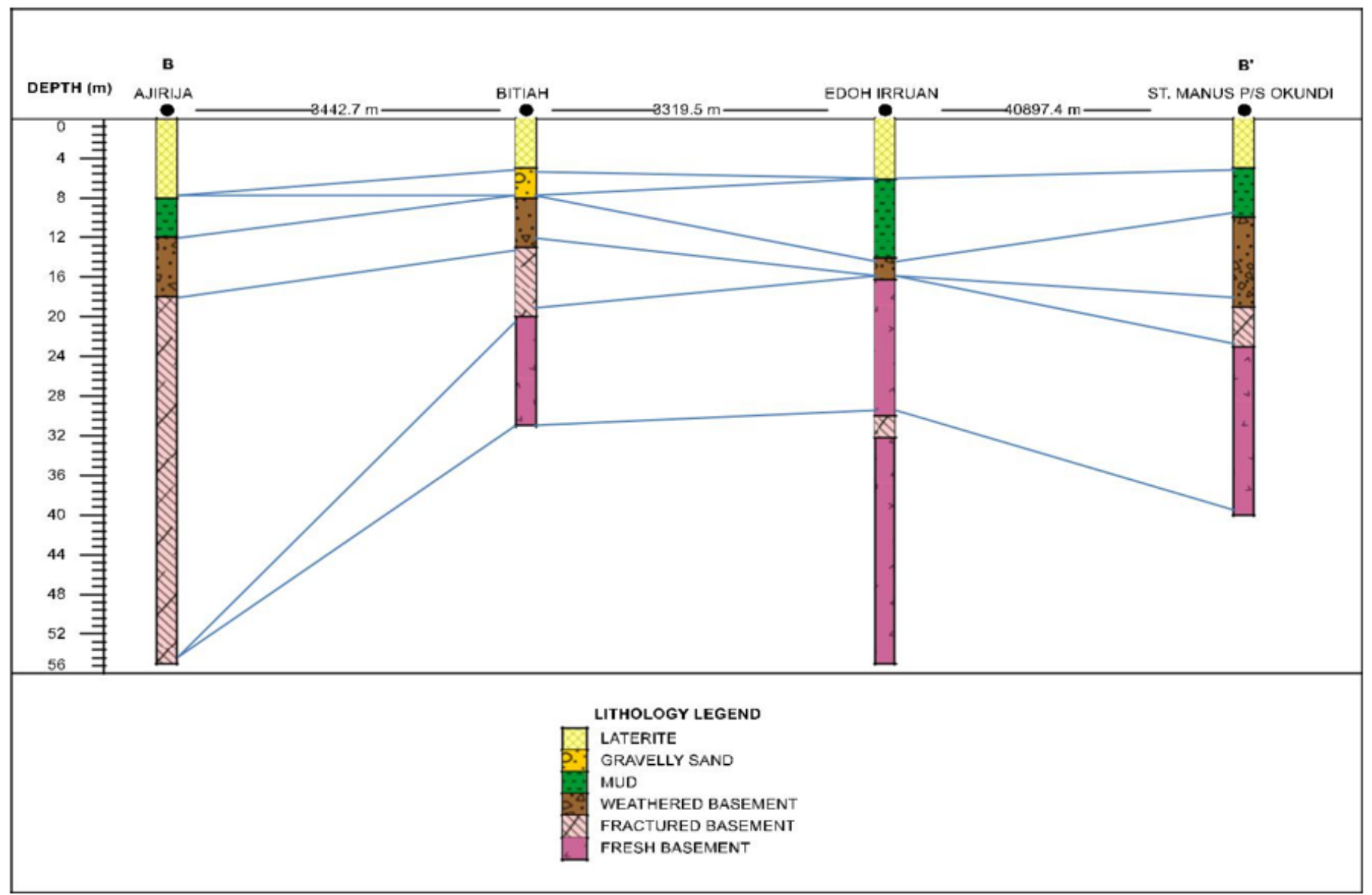

Figure 6

Geoelectric sections for traverse B $\otimes$ B1. 


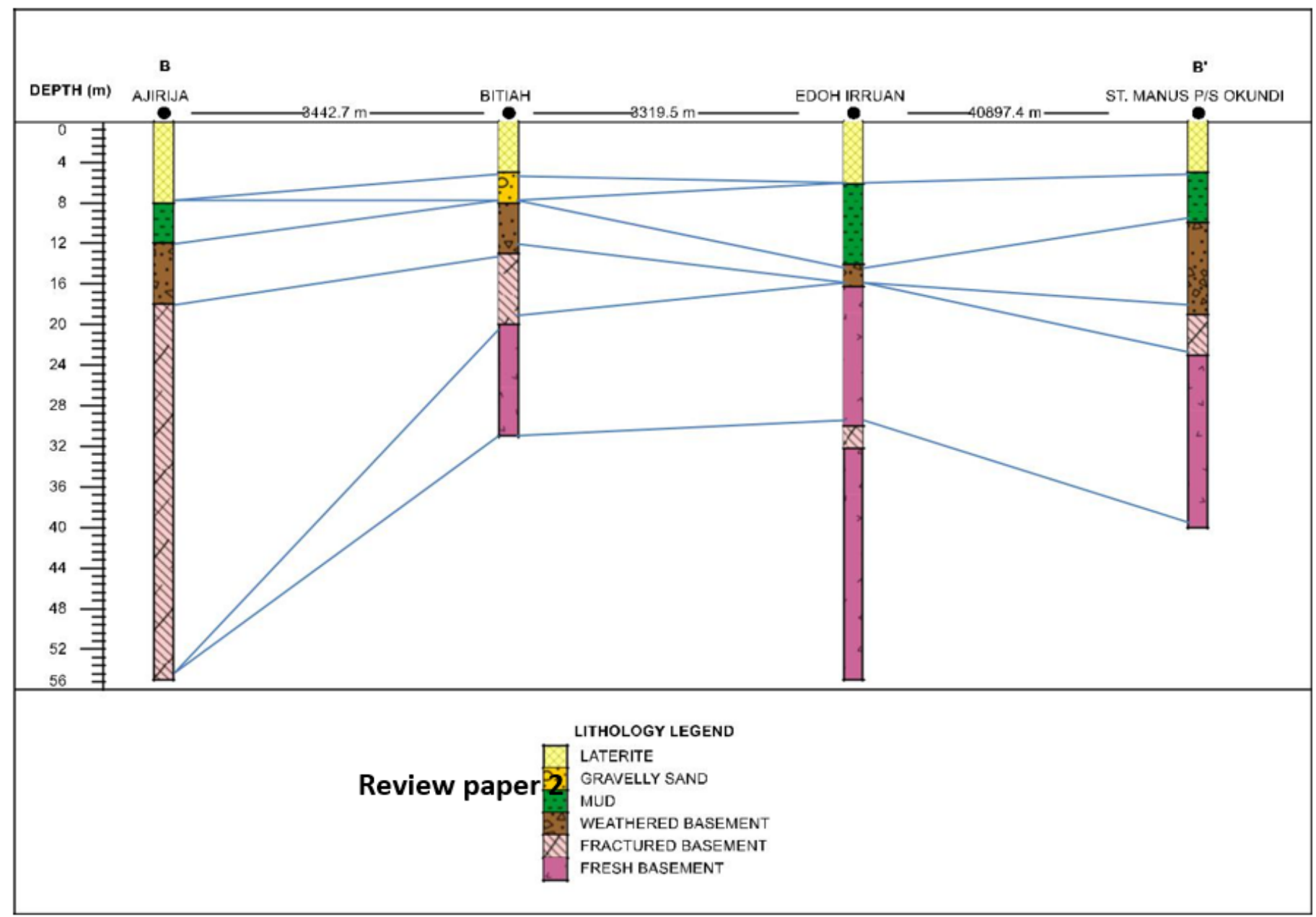

Figure 7

Geoelectric sections for transverse C-C1.

\section{Image not available with this version}

Figure 8

The VES results were used in the preparation of 2-D geoelectric sections, which shows the resistivity of the various subsurface layers and their respective thickness (Fig 5-8). Each section was prepared in accordance to the VES points in each transverse.

\section{Image not available with this version}

\section{Figure 9}

The overburden thickness at each sounding location was gridded and contoured to produce an Isopach map (Fig.9) of the overburden. An isopach map shows the spatial distribution of thicknesses within a locality. Note: The designations employed and the presentation 
of the material on this map do not imply the expression of any opinion whatsoever on the part of Research Square concerning the legal status of any country, territory, city or area or of its authorities, or concerning the delimitation of its frontiers or boundaries. This map has been provided by the authors.

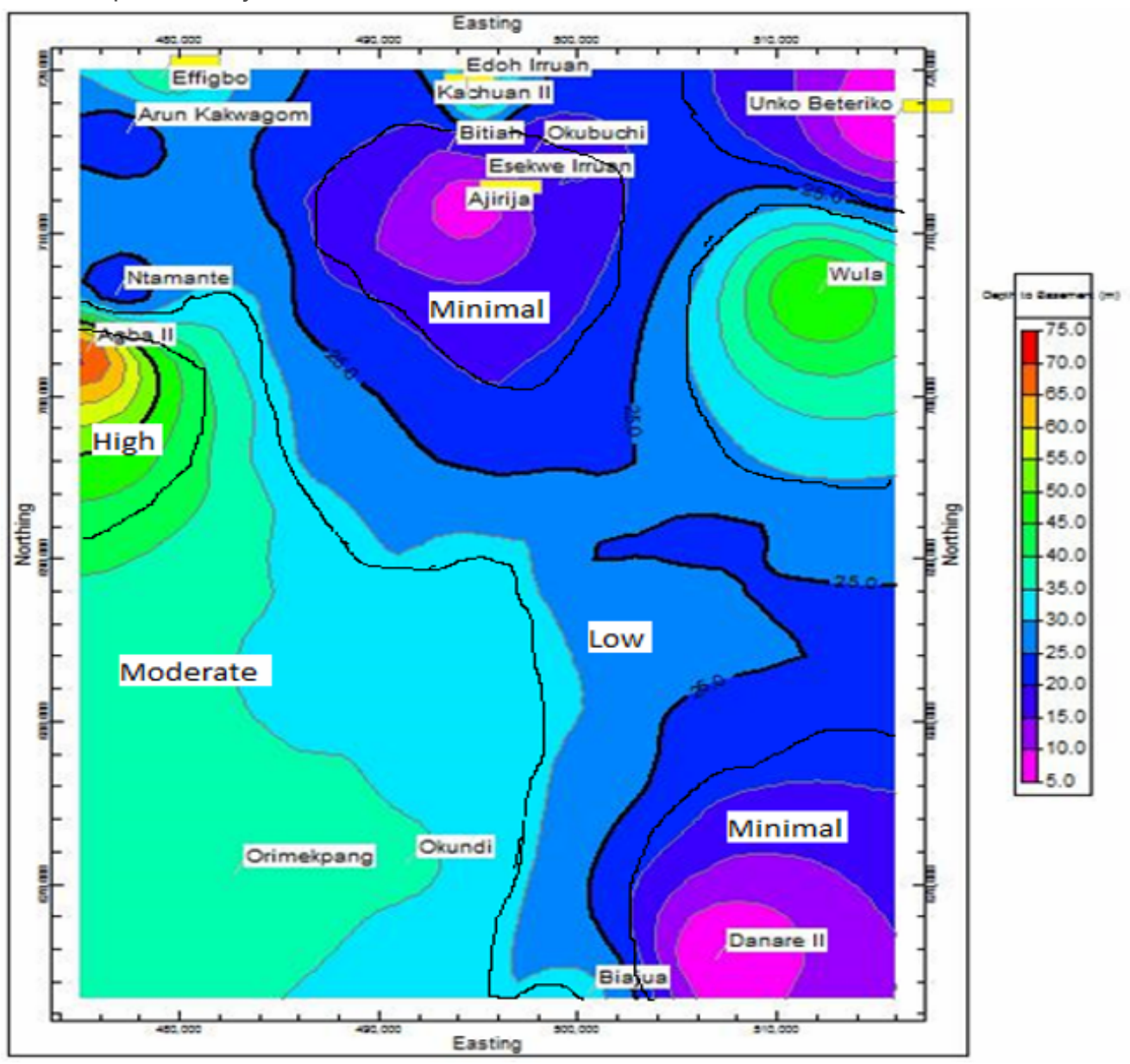

\section{Figure 10}

An Isopach Map of the Study Area. Note: The designations employed and the presentation of the material on this map do not imply the expression of any opinion whatsoever on the part of Research Square concerning the legal status of any country, territory, city or area or of its authorities, or concerning the delimitation of its frontiers or boundaries. This map has been provided by the authors. 


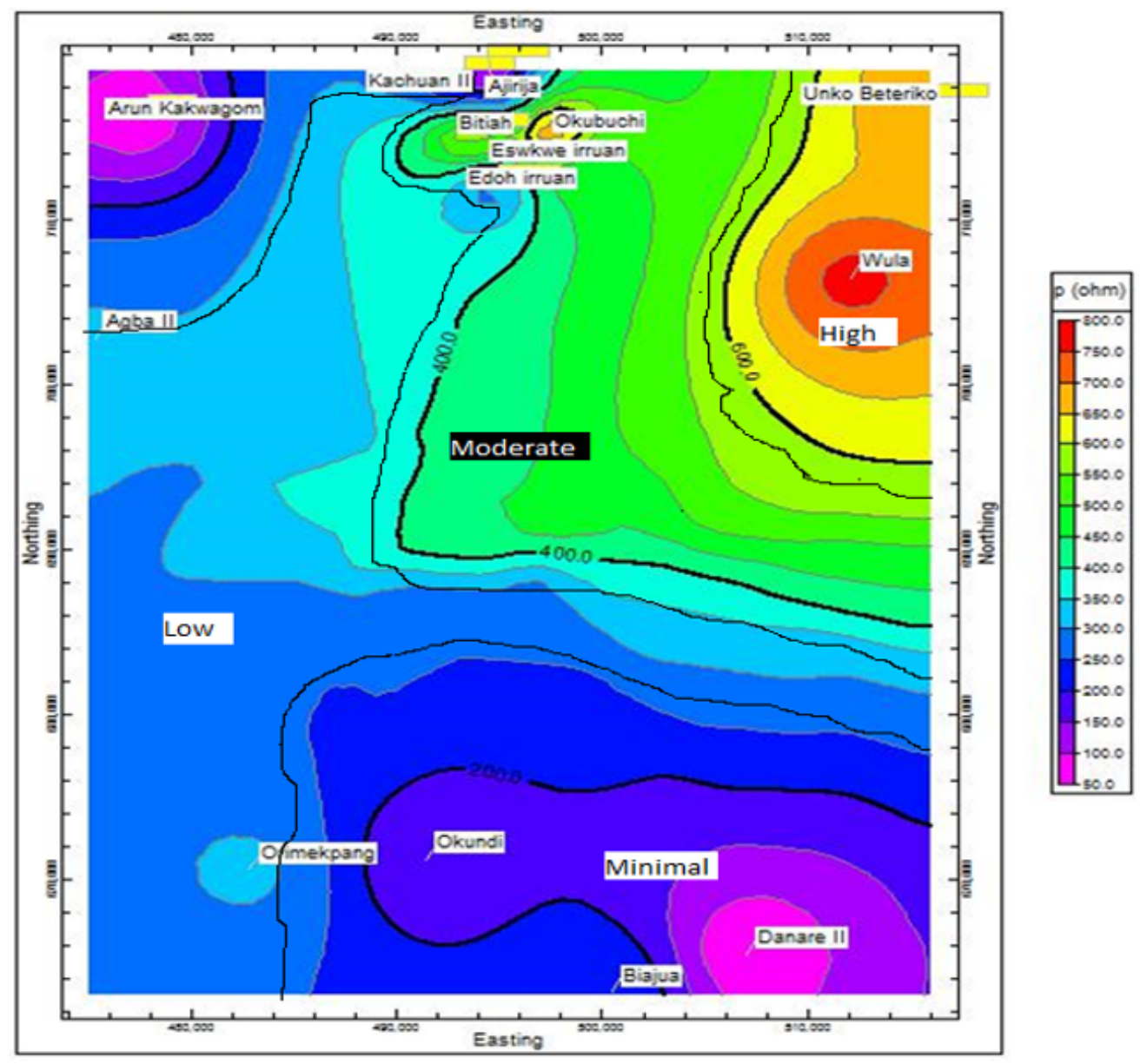

Figure 11

Iso resistivity map of weathered basement within the study area Note: The designations employed and the presentation of the material on this map do not imply the expression of any opinion whatsoever on the part of Research Square concerning the legal status of any country, territory, city or area or of its authorities, or concerning the delimitation of its frontiers or boundaries. This map has been provided by the authors. 


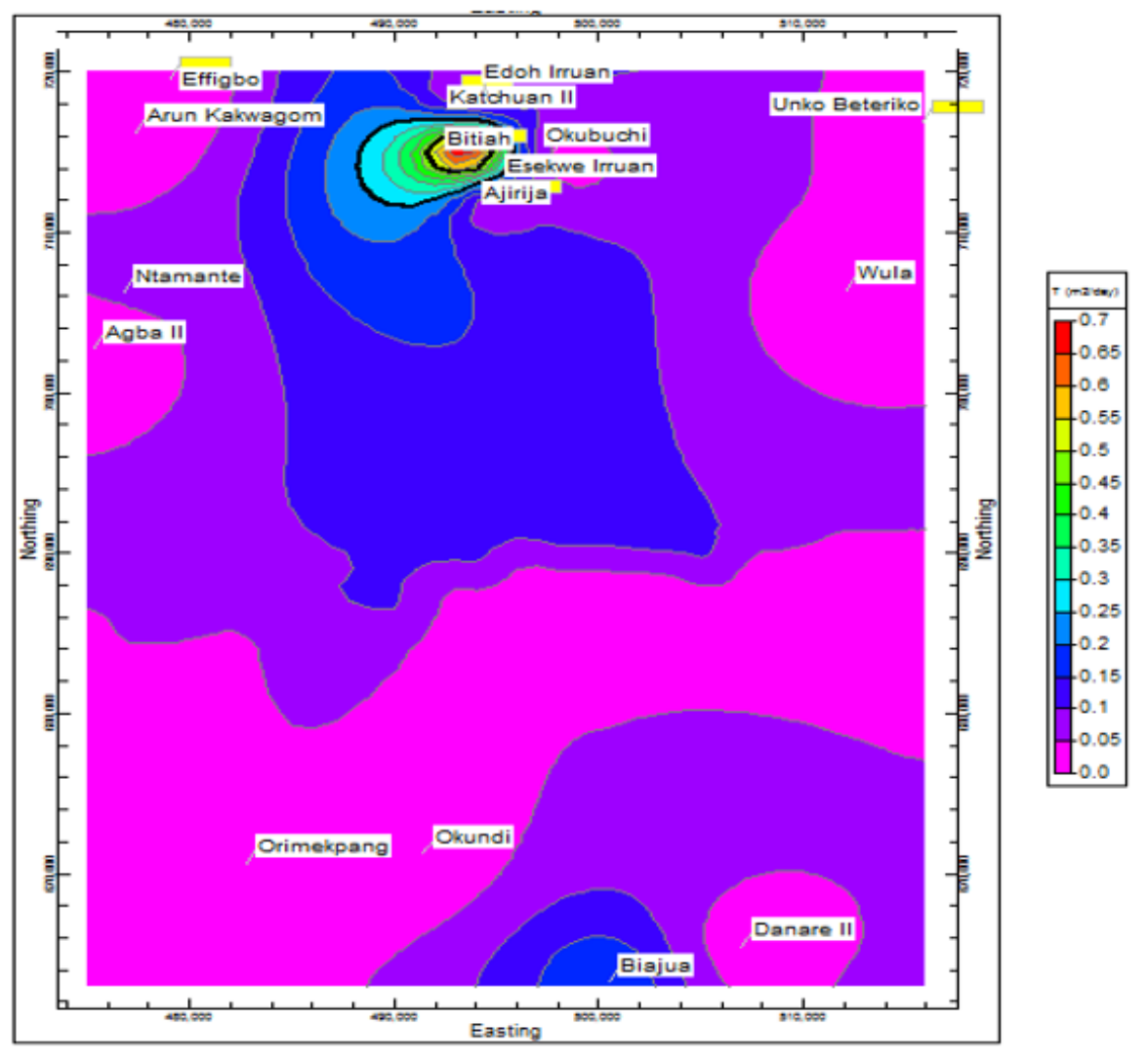

Figure 12

Transmissivity Map of the study Area. Note: The designations employed and the presentation of the material on this map do not imply the expression of any opinion whatsoever on the part of Research Square concerning the legal status of any country, territory, city or area or of its authorities, or concerning the delimitation of its frontiers or boundaries. This map has been provided by the authors. 